\title{
KEBIJAKAN FORMULASI HUKUM PIDANA DALAM RANGKA PENANGGULANGAN TINDAK PIDANA MALPRAKTIK KEDOKTERAN
}

\author{
PRIHARTO ADI , S.H.
}

\section{BAB I PENDAHULUAN}

\section{A. Latar Belakang Penelitian}

Sistem hukum Indonesia yang salah satu komponennya adalah hukum substantif, diantaranya hukum pidana, hukum perdata dan hukum administrasi tidak mengenal bangunan hukum malpraktik . Justru yang utama dan mendasar ada di dalam hukum kesehatan Indonesia yang berupa Undang - Undang Kesehatan No 23 Tahun 1992 secara resmi menyebut kesalahan atau kelalaian dalam melaksanakan profesi dalam Pasal 54 dan 55 , Lebih - lebih apabila ditinjau dari budaya hukum di Indonesia malpraktek merupakan sesuatu yang asing karena batasan mengenai malpraktik yang diketahui dan dikenal oleh kalangan profesi kedokteran dan hukum itu berasal dari alam pikiran barat yang nampaknya ingin diterapkan di Indonesia. Untuk itu masih perlu ada pengkajian secara khusus guna memperoleh suatu rumusan pengertian dan batasan istilah malpraktik di dalam rangka menanggulangi tindak pidana malpraktik kedokteran khususnya di dalam memberikan perlindungan hukum terhadap pasien sebagai korban malpraktik.

Tuntutan terhadap malpraktik kedokteran seringkali kandas di tengah jalan karena sulitnya pembuktian. Dalam hal ini pihak dokter perlu membela diri dan mempertahankan hak-haknya dengan mengemukakan alasan-alasan atas tindakannya. Baik penggugat dalam hal ini pasien, pihak dokter maupun praktisi ( hakim dan jaksa ) mendapat kesulitan dalam menghadapi masalah malpraktik kedokteran ini, terutama dari sudut teknis hukum atau formulasi hukum yang tepat untuk digunakan. Masalahnya terletak pada belum adanya hukum dan kajian hukum khusus tentang malpraktik kedokteran yang dapat dijadikan pedoman dalam menentukan dan menanggulangi adanya malpraktik kedokteran di Indonesia. Untuk itu maka perlu dikaji kembali kebijakan formulasi hukum pidana yang dapat dikaitkan dengan kelalaian atau malpraktik kedokteran khususnya di dalam memberikan perlindungan hukum 'terhadap korban mapraktik dalam hal ini pasien. 
Karena itulah maka perlu dibahas mengenai malpraktik kedokteran dari sudut kajian kebijakan formulasi hukum pidana, karena kajian malpraktik kedokteran dari sudut hukum sangatlah penting. Persoalan malpraktik kedokteran lebih dititikberatkan pada permasalahan hukum, karena malpraktik kedokteran adalah praktik kedokteran yang mengandung sifat melawan hukum sehingga menimbulkan akibat fatal bagi pasien.

Bagi masyarakat terutama para korban pertanyaan yang menjadi perhatian adalah mengapa begitu sulit membawa kasus malpraktik "dari meja operasi ke meja hijau". Apakah perangkat hukum dan peraturan perundangan yang ada tidak cukup untuk membawa persoalan malpraktik medik ke ranah hukum terutama hukum pidana, untuk itu perlu dikaji kembali mengenai kebijakan formulasi yang ada saat ini ( Undang Undang yang berkaitan dengan malpraktik kedokteran) dan kebijakan formulasinya yang akan datang di dalam menanggulangi tindak pidana malpraktik kedokteran. Khususnya di dalam memberikan perlindungan hukum terhadap pasien korban malpraktik.

\section{B. Perumusan Masalah}

1. Bagaimana kebijakan formulasi hukum pidana saat ini dalam menanggulangi tindak pidana malpraktik kedokteran?

2. Bagaimana Kebijakan formulasi hukum pidana yang akan datang dalam menanggulangi tindak pidana Malpraktik Kedokteran?

\section{Tujuan Penelitian}

1. Untuk mengetahui kebijakan formulasi undang - undang yang saat ini berlaku berkaitan dengan malpraktik kedokteran .

2. Untuk mengetahui dan menganalisa mengenai kebijakan formulasi yang harus dilakukan dalam rangka penanggulangan tindak pidana Malpraktik Kedokteran di masa yang akan datang.

\section{Metode Penelitian}

1. Metode pendekatan

Sasaran utama dalam penelitian ini pada masalah kebijakan formulasi yaitu mengenai perundang-undangan dalam menetapkan dan merumuskan tindak pidana malpraktik kedokteran, maka pendekatannya terutama ditempuh lewat pendekatan yuridis normatif yang bertumpu pada data sekunder dan ditunjang dengan pendekatan yuridis komparatif.

Pendekatan yuridis normatif yaitu dengan mengkaji atau menganalisis data sekunder yang berupa bahan - bahan hukum sekunder dengan memahami hukum sebagai perangkat peraturan atau norma positif di dalam perundang - undangan yang berlaku, jadi penelitian ini dipahami 
sebagai penelitian kepustakaan, yaitu penelitian terhadap bahan sekunder. ${ }^{1}$

\section{Spesifikasi Penelitian}

Spesifikasi penelitian dalam tesis ini adalah termasuk deskriptif analitis, yaitu menggambarkan peraturan perundangan yang berlaku dikaitkan dengan teori-teori hukum ,penelitian ini termasuk penelitian kepustakaan.

\section{Jenis dan Sumber Data}

Penelitian ini termasuk penelitian hukum normatif, maka jenis data yang digunakan adalah data sekunder. Data sekunder yang diteliti adalah sebagai berikut :

1) Bahan hukum primer yaitu bahan hukum yang mengikat seperti Sumbersumber hukum nasional yang berkaitan dengan pengaturan formulasi mengenai Tindak pidana malpraktik kedokteran dan Peraturan perundangan Singapura dengan melakukan kajian komparatif

2) Bahan hukum sekunder, yaitu bahan yang memberikan penjelasan tentang bahan hukum primer, yaitu berupa dokumen atau risalah perundang undangan .

3) Bahan hukum tersier yang memberikan penjelasan lebih mendalam mengenai bahan hukum primer maupun bahan hukum sekunder antara lain :

\footnotetext{
${ }^{1}$ Soerjono Soekanto, Penelitian Hukum Normatif suatu tinjauan singkat, Raja Grafindo, Jakarta, 1985, halaman 15
}

a. Ensiklopedia Indonesia

b. Kamus Hukum

c. Kamus Bahasa Inggris Indonesia

\section{Metode Pengumpulan Data}

Mengingat penelitian ini memu satkan perhatian pada data sekunder, maka pengumpulan data ditempuh dengan melakukan penelitian kepustakaan dan studi dokumen. Di dalam pengumpulan data, sebanyak mungkin data yang diperoleh dan dikumpulkan diusahakan mengenai masalah-masalah yang berhu bungan dengan penelitian ini. Data atau sumber sekunder berupa KUHP, Undang - Undang Nomor 23 Tahun 1997 Jonctu Undang - Undang Nomor 36 Tahun 2009 Tentang Kesehatan Undang-Undang tentang Praktik Dokter Nomor 29 Tahun 2004 Pasca putusan Mahkamah Konstitusi dan yang berkaitan dengan malpraktik kedokteran, Rancangan (Konsep) KUHP 2008, sumber-sumber hukum dan perundang-undangan negara Singapura mengenai malpraktik kedokteran atau yang berhubungan dengan kesehatan.

\section{Metode Analisis Data}

Data yang diperoleh dari penelitian dikumpulkan dan dilakukan analisis dengan jalan menafsirkan dan mengkonstruksikan pernyataan yang terdapat dalam dokumen dan perundang undangan. Normatif karena penelitian ini bertitik tolak dari peraturan - peraturan yang ada sebagai norma hukum positif, 
sedangkan kualitatif berarti analisa data yang bertitik tolak pada usaha penemuan asas - asas dan informasi baru.

\section{BAB II \\ TINJAUAN PUSTAKA}

\section{A.Hubungan Dokter Pasien}

Hubungan antara dokter dan pasien secara yuridis dapat dimasukkan ke dalam golongan kontrak . Suatu kontrak adalah pertemuan pikiran ( meeting of minds) dari dua orang mengenai suatu hal. Pihak pertama mengikatkan diri untuk memberikan pelayanan, sedangkan pihak kedua menerima pemberian pelayanan tersebut. Pasien datang kepada dokter untuk diberikan pelayanan pengobatan sedangkan dokter menerima untuk memberikannya.

Dengan demikian maka sifat hubungannya mempunyai 2 ciri :

1. Adanya suatu persetujuan (consensual agreement ), atas dasar saling menyetujui dari pihak dokter dan pasien tentang pemberian pelayanan pengobatan.

2. Adanya suatu kepercayaan (fiduciary), karena hubungan kontrak tersebut berdasarkan saling percaya mempercayai satu sama lain . ${ }^{2}$

${ }^{2}$ Guwandi, Dokter Pasien dan Hukum, Fakultas Kedokteran UI, Jakarta , 1996. hal 11.

\section{B. Pengertian Malpraktik Medik}

Malapraktik telah digunakan secara luas di Indonesia sebagai terjemahan " malpractice ", sedangkan kelalaian adalah terjemahan untuk " Negligence " Ada beberapa pendapat sarjana mengenai pengertian malpraktik :

a. Veronica mengemukakan malapraktik yaitu kesalahan dalam menjalankan profesi yang timbul sebagai akibat adanya kewajiban - kewajiban yang harus dilakukan oleh dokter. ${ }^{3}$

b. Danny Wiradharma memandang malpraktek dari sudut tanggung jawab dokter yang berada dalam suatu perikatan dengan pasien, yaitu dokter tersebut melakukan praktik yang buruk. ${ }^{4}$

c. Ngesti Lestari mengartikan malpraktek secara harfiah sebagai pelaksanaan atau tindakan yang salah. ${ }^{5}$

Dari beberapa pengertian tentang malpraktik medik di atas semua sarjana sepakat untuk mengartikan malpraktik medik sebagai kesalahan dokter yang karena tidak menggunakan ilmu pengetahuan dan tingkat ketrampilan sesuai dengan standar profesinya yang

${ }^{3}$ Veronika Komalawati, Hukum dan Etika dalam Praktik Dokter, Sinar Harapan,Jakarta 1989.

${ }^{4}$ Danny Wiradharma, Penuntun Kuliah Kedokteran dan Hukum Kesehatan, Egc,Jakarta,1999.

${ }^{5}$ Ngesti Lestari, "Masalah Malpraktek Etik Dalam Praktek Dokter", Kumpulan Makalah Seminar tentang Etika dan Hukum Kedokteran diselenggarakan oleh RSUD Dr. Saiful Anwar , Malang, 2001. 
akhirnya mengakibatkan pasien terluka atau cacat bahkan meninggal.

\section{Pertanggungjawaban Dalam Hukum Pidana}

Dipidananya seseorang tidaklah cukup apabila orang itu telah melakukan perbuatan yang bertentangan dengan hukum atau bersifat melawan hukum. Jadi meskipun perbuatannya memenuhi rumusan delik dalam Undang - Undang dan tidak dibenarkan, hal tersebut belum memenuhi syarat untuk penjatuhan pidana. Untuk pemidanaan masih perlu adanya syarat, yaitu bahwa orang yang melakukan perbuatan itu mempunyai kesalahan atau bersalah .

Sehubungan dengan hal tersebut berlaku asas " tiada pidana tanpa kesalahan " asas itu dianut oleh KUHP Indonesia dan juga negara - negara lain, akan bertentangan dengan rasa keadilan apabila ada orang yang dijatuhi pidana padahal ia sama sekali tidak bersalah. Orang tidak mungkin dipertanggunggjawabkan ( dijatuhi pidana ) kalau dia tidak melakukan perbuatan pidana, akan tetapi meskipun melakukan perbuatan pidana, dia tidak selalu dapat dipidana.

\section{INFORMED CONSENT}

Salah satu hal penting yang tidak boleh dilupakan dalam rangka memperoleh persetujuan pasien adalah memberikan infor-masi terlebih dahulu , yang kita kenal dengan istilah Informed Consent yaitu suatu izin atau pernyataan setuju dari pasien yang diberikan secara bebas, sadar dan rasional setelah ia mendapat informasi yang dipahaminya dari dokter tentang penyakitnya. ${ }^{6}$

\section{E. KEGAWATAN MEDIK}

Issue pertama yang perlu dikemukakan di sini adalah yang menyangkut batasan atau definisi dari kegawatan medik itu sendiri. Hal ini penting sebab beberapa sengketa hukum yang timbul antara health care reciever dan health care provider, penyelesaiannya sering memerlukan kejelasan lebih dahulu tentang batasannya. ${ }^{7}$

Sejauh ini memang belum ada batasan yuridisnya dan tentunya menjadi tugas kalangan medik untuk merumuskannya, sebab rumusan itulah nantinya yang akan dijadikan acuan penting oleh hakim bagi penyelesaian sengketa hukum. Dengan kata lain rumusan tersebut akan dijadikan sumber hukum yang bersifat persuasif mengingat hukum positifnya di Indonesia belum ada

\footnotetext{
${ }^{6}$ Guwandi , Trilogi Rahasia Kedokteran , Balai Penerbit FKUI, Jakarta, 1992 , hal 17-30.

${ }^{7}$ Ngesti Lestari, "Masalah Malpraktek Etik Dalam Praktek Dokter ", Kumpulan Makalah Seminar tentang Etika dan Hukum Kedokteran diselenggarakan oleh RSUD Dr. Saiful Anwar, Malang, 2001
} 


\section{BAB III \\ HASIL PENELITIAN DAN PEMBAHASAN}

A. Kebijakan Formulasi Hukum

Pidana Saat ini Mengenai

Penanggulangan Tindak Pidana

Malpraktik Kedokteran

1. Kitab Undang - Undang

Hukum Pidana ( KUHP $)^{8}$

a. Kejahatan Terhadap Pemalsuan Pasal 267 KUHP

(1) Seorang dokter yang dengan sengaja memberi surat keterangan palsu tentang ada atau tidaknya penyakit, kelemahan atau cacat, diancam dengan pidana penjara paling lama empat tahun

Pasal 267 KUHP di atas memang pasal khusus yang hanya dikenakan bagi dokter. Maksudnya yaitu hanya orang tertentu yang mempunyai sifat atau kualitas pribadi sebagai dokter saja yang dapat dijadikan subjek hukum yang melakukan kejahatan pemalsuan ini. Agar rumusan Pasal 267 ini bisa dikenakan kepada dokter, unsur sengaja harus terpenuhi, karena bisa saja terjadi dokter salah dalam menentukan diagnosa, sehingga salah pula dalam menerbitkan surat keterangan yang dibuatnya. Saran penulis terhadap pasal ini sebaiknya dimasukkan juga unsur kelalaian yang dilakukan oleh dokter.

\footnotetext{
${ }^{8}$ Moeljatno,KUHP. Penerbit Bumi Aksara,1999
}

\section{b. Pengguguran Kandungan}

Pengguguran kandungan terdapat di dalam Pasal 299, 346, 348 dan pasal 349 KUHP. Sebagai salah satu contoh dapat dilihat dalam :

Pasal 299

(1) Barang siapa dengan sengaja mengobati seorang pasien atau menyuruhnya supaya diobati, dengan diberitahukan atau ditimbulkan harapan, bahwa karena pengobatan itu hamilnya dapat digugurkan ,diancam dengan pidana penjara paling lama empat tahun atau denda paling banyak tiga ribu rupiah.

Jika kita melihat Pasal 299, 346, 348 dan pasal 349 KUHP di atas berkaitan dengan upaya abortus criminalis karena di dalamnya terdapat unsur adanya upaya menggugurkan kandungan tanpa adanya indikasi medis. Dapat dicermati bahwa masalah menggugurkan kandungan atau abortus provokatus ini diatur dengan ketat sekali di dalam KUHP, sebab orang ( Dokter atau orang awam) yang sengaja mengobati perempuan yang sedang mengandung, dengan memberi pengharapan bahwa dengan obat yang diberikannya itu dapat menggugurkan kandungan saja, dapat diancam dengan pidana yang cukup berat, yaitu empat tahun penjara ( Pasal 299 KUHP ). Ketentuan ini sebetulnya membuat dilemma dan menimbulkan ketakutan bagi dokter karena apabila ada indikasi medis dimana dalam keadaan darurat untuk 
menyelamatkan jiwa Ibu hamil, mengharuskan menggugurkan kandungan ibu hamil tersebut, oleh karena itu menurut penulis sebaiknya ketentuan ini diberi pengecualian bagi dokter apabila ada indikasi medis, dengan demikian dapat memberikan rasa tenang atau nyaman bagi dokter di dalam melaksanakan tugasnya menyelamatkan nyawa pasien dan untuk menghindari tuduhan adanya malpraktik kedokteran

\section{c. Tentang Penganiayaan}

Pasal 35

(1) Penganiayaan diancam dengan pidana penjara paling lama dua tahun delapan bulan atau denda paling banyak tiga ratus rupiah

(2) Jika Perbuatan mengakibatkan luka luka berat yang bersalah dikenakan pidana - paling lama lma tahun.

(3) Jika mengakibatkan mati, dikenakan pidana penjara paling lama tujuh tahun

Dalam praktik hukum mengenai masalah yang berhubungan dengan kesehatan dipersoalkan juga tentang akibat rasa sakit sebagai satu-satunya tujuan penganiayaan, artinya jika rasa sakit yang disadari itu tidak dapat dihindari, dalam upaya mencapai tujuan yang patut, misalnya dokter menyunat anak, dimana maksud mencapai tujuan yang lebih patut dan timbul rasa sakit tidak dapat dihindari maka bukan termasuk penganiayaan. d. Kejahatan Terhadap Nyawa

Pasal - pasal kejahatan terhadap nyawa yang dapat dikaitkan dengan Euthanasia yaitu Pasal 338, 340 , 344, 345 , 359 KUHP jika dihubungkan dengan dunia kesehatan sebagai upaya penanggulangan tindak pidana malpraktik di Indonesia menegaskan bahwa euthanasia baik aktif maupun pasif tanpa permintaan adalah dilarang. Demikian pula dengan euthanasia aktif dengan permintaan.

\section{Undang - Undang Nomor 36 Tahun 2009 Tentang kesehatan}

a. Berkaitan dengan Kelalaian

Pasal 29 Undang - Undang Nomor 36 Tahun 2009

" Dalam hal tenaga kesehatan diduga melakukan kelalaian dalam menjalankan profesinya, kelalaian tersebut harus diselesaikan terlebih dahulu melalui mediasi “

Kalau penulis cermati Undang Undang Nomor 36 Tahun 2009 Pasal 29 tersebut di atas mengenai kelalaian tentu merupakan kebijakan formulasi hukum kesehatan yang baik sebagai upaya untuk mencegah terjadinya tindak pidana malpraktik kedokteran. Pasal mengenai kelalaian ini juga terdapat di Pasal 54 Undang - Undang Nomor 23 Tahun 1992 Tentang Kesehatan .

b. Berkaitan Dengan Perlindungan Pasien Pasal 56 
c. Setiap orang berhak menerima atau menolak sebagian atau seluruh tindakan pertolongan yang akan diberikan kepadanya setelah menerima dan memahami informasi mengenai tindakan tersebut secara lengkap.

d. Mengenai Ganti Rugi

\section{Pasal 58}

(1) Setiap orang berhak menuntut ganti rugi terhadap seseorang, tenaga kesehatan, dan/atau penyelenggara kesehatan yang menimbulkan kerugian akibat kesalahan atau kelalaian dalam pelayanan kesehatan yang diterimanya.

(2) Tuntutan ganti rugi sebagaimana dimaksud pada ayat (1) tidak berlaku bagi tenaga kesehatan yang melakukan tindakan penyelamatan nyawa atau pencegahan kecacatan seseorang dalam keadaan darurat.

e. Mengenai Transplantasi Organ

\section{Pasal 64}

(1)Penyembuhan penyakit dan pemulihan kesehatan dapat dilakukan melalui transplantasi organ dan/atau jaringan tubuh, implan obat dan/atau alat kesehatan, bedah plastik dan rekonstruksi, serta penggunaan sel punca.

(2) Transplantasi organ dan/atau jaringan tubuh sebagaimana dimaksud pada ayat (1) dilakukan hanya untuk tujuan kemanusiaan dan dilarang untuk dikomersialkan.
(3) Organ dan/ atau jaringan tubuh dilarang diperjualbelikan dengan dalih apapun.

\section{c. Undang - Undang Nomor 29 Tahun 2004 Tentang Praktik Dokter}

Putusan Mahkamah Konstitusi No 4/PUU/ V/2007 terhadap uji materiil Undang - Undang Nomor 29 Tahun 2004 Menyatakan permohonan para Pemohon dikabulkan untuk sebagian;

Menyatakan Pasal 75 Ayat (1) dan Pasal 76 sepanjang mengenai katakata "penjara paling lama 3 (tiga) tahun atau" dan Pasal 79 sepanjang mengenai kata-kata “kurungan paling lama 1 (satu) tahun atau” serta Pasal 79 huruf c sepanjang mengenai kata-kata “atau huruf $\boldsymbol{e}$ ” Undang-Undang Nomor 29 Tahun 2004 tentang Praktik Kedokteran (Lembaran Negara Republik Indonesia Tahun 2004 Nomor 116, Tambahan Lembaran Negara Republik Indonesia Nomor 4431) bertentangan dengan UndangUndang Dasar Negara Republik Indonesia Tahun 1945;

Menyatakan Pasal 75 Ayat (1) dan Pasal 76 sepanjang mengenai katakata "penjara paling lama 3 (tiga) tahun atau" dan Pasal 79 sepanjang mengenai kata-kata “kurungan paling lama 1 (satu) tahun atau” serta Pasal 79 huruf c sepanjang mengenai kata-kata 
“atau huruf $\boldsymbol{e}$ ” Undang-Undang Nomor 29 Tahun 2004 tentang Praktik Kedokteran (Lembaran Negara Republik Indonesia Tahun 2004 Nomor 116, Tambahan Lembaran Negara Republik Indonesia Nomor 4431) tidak mempunyai kekuatan hukum mengikat;

Kalau dianalisa Pasal 75 (1), Pasal 76, Pasal 79 huruf a dan Pasal 79 huruf c sebelum putusan mahkamah konstitusi materi muatan yang terdapat di dalam Undang- Undang Nomor 29 Tahun 2004 telah menimbulkan kriminalisasi terhadap tindakan dokter yang berpraktik kedokteran yang tidak dilengkapi STR, SIP dan tidak memasang papan nama, serta tidak menambah ilmu pengetahuan dengan ancaman pidana yang cukup berat dan denda yang sangat tinggi .

Hal demikian dapat menimbulkan rasa takut bagi dokter di dalam melakukan pengobatan terhadap pasien, sehingga dokter tidak tenang di dalam melaksanakan tugasnya untuk menolong pasien atau korban tersebut. Setelah putusan mahkamah konstitusi diharapkan dokter dapat lebih tenang sehingga dapat bekerja dengan baik untuk menyelamatkan Pasien. Pekerjaan dokter merupakan profesi berbeda dengan okupasi, sehingga pembentuk Undang - Undang dalam hal ini legislatif harus hati-hati dalam menentukan aspek pidana. Hukum pidana harus benar-benar digunakan sebagai ultimum remidium bukan premium remidium, lebih efektif dengan penerapan hukum administratifasien. Dengan putusan Mahkamah Konstitusi tersebut setidaknya dokter dapat bekerja lebih tenang dan nyaman di dalam usaha menyelamatkan nyawa Pasien .

\section{B. Kebijakan Formulasi Yang Akan Datang}

Untuk menentukan kebijakan formulasi yang akan datang maka penulis menggunakan kajian perbandingan diantaranya KUHP, Konsep KUHP 2008, Undang - Undang Nomor 29 Tahun 2004 Pasca Putusan Mahlamah Konstitusi, KUHP Singapura

\section{a. Konsep KUHP 2008}

Tentang Mengakibatkan mati atau luka karena kealpaan

Pasal 592 Konsep KUHP 2009

\begin{tabular}{|c|c|}
\hline p KUHP 2008 & KUHP \\
\hline $\begin{array}{l}\text { Pasal } 592 \\
\text { Setiap orang yang ka- } \\
\text { rena kealpaannya me- } \\
\text { ngakibatkan orang lain } \\
\text { luka sehingga timbul } \\
\text { penyakit atau halangan } \\
\text { menjalankan jabatan, } \\
\text { profesi,atau mata pen- }\end{array}$ & 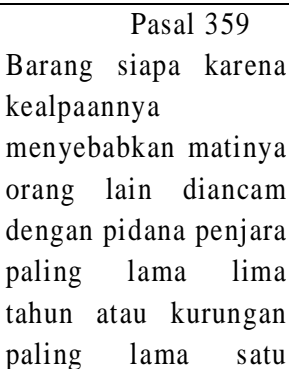 \\
\hline
\end{tabular}




\begin{tabular}{|c|c|}
\hline $\begin{array}{l}\text { caharian selama waktu } \\
\text { tertentu, dipidana de- } \\
\text { ngan pidana penjara } \\
\text { paling lama } 2 \text { ( dua) } \\
\text { tahun atau denda paling } \\
\text { banyak kategori III }\end{array}$ & tahun. \\
\hline $\begin{array}{l}\text { Pasal } 593 \\
\text { Jika tindak pidana se- } \\
\text { bagaimana dimaksud } \\
\text { dalam Pasal } 592 \text { dila- } \\
\text { kukan dalam menjalan- } \\
\text { kan suatu jabatan atau } \\
\text { profesi, maka pidana- } \\
\text { nya dapat ditambah } \\
\text { dengan } 1 / 3 \text { ( sepertiga ) }\end{array}$ & $\begin{array}{l}\text { Pasal } 360 \\
\text { Barangsiapa karena } \\
\text { ke-alpaannya } \\
\text { menyebab-kan orang } \\
\text { lain menda-pat luka - } \\
\text { luka berat, diancam } \\
\text { dengan dengan pidana } \\
\text { penjara paling lama } \\
\text { lima tahun atau } \\
\text { kurungan paling lama } \\
\text { satu tahun }\end{array}$ \\
\hline
\end{tabular}
duanya adalah mengenai jenis dan lamanya pidana yang dijatuhkan . Dalam KUHP dikenal dengan pidana kurungan sedangkan dalam konsep tidak lagi mengenal pidana kurungan. ${ }^{9}$

Jenis dan lamanya pidana yang dijatuhkan yaitu :

1. Karena kelalaian mengakibatkan luka

Dalam KUHP diancam pidana penjara paling lama Sembilan bulan atau kurungan paling lama enam bulan, atau denda paling banyak tiga ratus rupiah. Sedangkan di dalam konsep diancam dengan pidana penjara paling lama dua

\footnotetext{
${ }^{9}$ Pasal 65 ayat (1) Konsep KUHP 2006, Pidana pokok terdiri atas pidana penjara , pidana tutupan, pidana pengawasan, pidana denda, dan pidana kerja sosial.
}

tahun atau denda paling banyak Kategori III

2. Karena kelalaian mengakibatkan luka berat

Dalam KUHP diancam pidana penjara paling lama lima tahun atau kurungan paling lama satu tahun , sedangkan dalam konsep diancam pidana penjara paling lama tiga tahun atau denda paling banyak Kategori IV

3. Karena kelalaian mengakibatkan mati

Dalam KUHP diancam pidana penjara paling lama lima tahun atau kurungan paling lama satu tahun , sedangkan dalam konsep diancam pidana penjara paling lama lima tahun atau denda paling banyak kategori IV.

Pasal 593 Konsep 2008 merupakan Pasal pemberatan pidana bagi pelaku dalam menjalankan suatu jabatan atau pencaharian, melakukan tindak pidana yang disebut dalam Pasal 592 Konsep. Pidana bagi pelaku yang melakukan perbuatan dalam menjalankan suatu jabatan atau profesi ditambah 1/3 (sepertiga ) dari pidana bagi pelaku yang bukan dalam menjalankan suatu jabatan atau profesi. Pasal ini merupakan suatu bentuk perlindungan juga terhadap pasien dalam hal terjadinya kelalaian atau kealpaan yang dilakukan oleh dokter dalam pelayanan kesehatan.

\section{b. KUHP Singapura}

Tentang Mengakibatkan mati atau luka karena kealpaan

Section 304 A 
Whoever causes the death of any person by doing any rash or negligent act not amounting to culpable homicide, shall be punished with imprisonment for a term which may extend to two years, or with fine, or with both ${ }^{10}$

\begin{tabular}{|l|l|}
\hline KUHP Singapura & \multicolumn{2}{|c|}{ KUHP Indonesia } \\
\hline Pasal 304 A & \multicolumn{2}{|c|}{ Pasal 359 } \\
Barangsiapa menye- & Barang siapa karena \\
babkan kematian sese- & kealpaanny menye- \\
orang yang dilakukan & babkan matinya orang \\
dengan gegabah atau & lain diancam dengan \\
kelalaian, perbuatan & pidana penjara paling \\
tersebut tidak sama & lama lima tahun atau \\
dengan pembunuhan & kurungan paling lama \\
bersalah , dapat & satu tahun \\
dipidana dengan pida- \\
na penjara untuk \\
jangka waktu paling \\
lama dua tahun atau \\
denda, atau keduanya.
\end{tabular}

Tindak pidana dalam pasal $304 \mathrm{~A}$ ini , sama dengan tindak pidana dalam pasal 359 KUHP Indonesia, tetapi rumusan pidananya berbeda. Dalam KUHP Singapura pidananya dirumuskan secara alternatif - kumulatif yaitu pidana penjara paling lama dua tahun atau denda , atau keduanya, yang dimaksud dengan keduanya adalah dipidana dengan pidana penjara paling lama dua tahun ditambah denda. Dalam KUHP Indonesia pidananya dirumuskan secara alternative yaitu

${ }^{10}$ Republik of Singapore Chapter 103, Penal Code, Arrangement of Section, Edition of 1970 pidana penjara paling lama lima tahun atau kurungan paling lama 1 tahun .

Dengan memperhatikan dan menganalisa serta membandingkan KUHP, Konsep KUHP 2008, KUHP Singapura maka dapat diambil kesimpulan bahwa kebijakan hukum pidana yang akan datang :

Berkaitan dengan kebijakan hukum pidana yang akan datang yang berhubungan dengan penanggulangan tindak pidana malpraktik kedokteran dirasakan perlu menggunakan sistem pidana minimum khusus sebagaimana di dalam konsep. Menurut Barda Nawawi Arief adanya pidana minimum khusus untuk delik - delik tertentu mempunyai suatu landasan antara lain

1) Untuk mengurangi adanya disparitas pidana

2) Untuk memenuhi tuntutan masyarakat yang menghendaki adanya standar minimal yang objektif untuk delik delik yang sangat dicela dan merugikan atau membahayakan masyarakat atau negara

3) Untuk lebih mengefektifkan prevensi umum ${ }^{11}$

Mengenai Pertanggungjawaban korporasi sebenarnya telah diatur di dalam Pasal 41 ayat 2 Undang - Undang Praktik kedokteran yaitu membuat daftar dokter atau dokter gigi yang melakukan praktik kedokteran di sarana pelayanan

\section{${ }^{11}$ Barda Nawawi Arief, Bunga Rampai}

Kebijakan Hukum Pidana, PT. Citra Adiya Bakti, Bandung, 1996 
kesehatan yang bersangkutan, tetapi sanksi terhadap pelanggaran kewajiban tersebut tidak diatur secara jelas mengenai sanksi yang dapat dijatuhkan.

Sanksi yang berkaitan dengan korporasi hanya yang berkaitan dengan larangan yang tercantum dalam Pasal 42 Undang - Undang Praktik kedokteran dimana sarana pelayanan kesehatan dilarang mengizinkan dokter berpraktik tanpa ada surat izin praktik. Ketentuan tentang sanksi yang berkaitan dengan korporasi tersebut diatur di dalam Pasal 80 ayat 2 Undang - Undang Praktik kedokteran. Oleh karena itulah maka kebijakan formulasi hukum pidana yang akan datang khususnya yg terdapat di dalam Undang - Undang 29 Tahun 2004 dapat diperluas tidak hanya terpusat pada pelanggaran membuat daftar dokter semata.

\section{B AB IV PENUTUP}

\section{A.Kesimpulan}

1. Sanksi terhadap korporasi diatur di dalam Pasal 80 Undang - Undang Praktik Kedokteran namun sanksi tersebut hanya terbatas pada pelanggaran surat Izin Praktik yang dilakukan oleh dokter.

2. Dalam hukum positif Indonesia baik KUHP, Undang - undang Nomor 36 Tahun 2009 tentang kesehatan , Undang - Undang Nomor 29 Tahun 2004 tentang Praktek Dokter Pasca putusan Mahkamah konstitusi tidak diatur secara khusus atau tidak dikenal adanya istilah malpractice medic.

3. Kebijakan formulasi yang akan datang sebaiknya perlu diatur juga mengenai pertanggungjawaban korporsi dalam hal tindakan medis yang telah dilakukan oleh dokter yang mengakibatkan kerugian di pihak pasien dalam hal terjadinya malpraktik medik, ini sebagai bentuk pemberian perlindungan terhadap korban malpraktik sebagai upaya menanggulangi tindak pidana malpraktik kedokteran di masa yang akan datang

4. Kebijakan formulasi hukum pidana yang akan datang sebaiknya mengatur mengenai masalah kelalaian dokter di dalam melakukan upaya atau tindakkan medis yang berakibat pada hilangnya nyawa orang .

\section{B. SARAN}

1. Sebaiknya di dalam Undang Undang Nomor 29 Tahun 2004 Tentang Praktik Kedokteran dijelaskan mengenai pengertian malpraktik kedokteran sehingga masyarakat umum, dokter, dan dunia kesehatan menjadi paham apa sesungguhnya malpraktik kedokteran dan mengetahui batasan - batasan mengenai tindak pidana malpraktik kedokteran ini .

2. Bagi aparat penegak hukum, baik penyidik penuntut umum dan hakim 
harus hati - hati di dalam menentukan pasal mana yang dapat dikenakan terhadap kasus malpraktik.karena di dalam dunia kedokteran, seorang dokter dalam menangani Pasien tidak ada dua penyakit yang sama persis antara pasien satu dengan pasien yang lainnya.

3. Hukum Pidana merupakan Ultimum Remedium artinya hukum pidana sebaiknya digunakan sebagai obat terakhir atau langkah terakhir apabila cara - cara penyelesaian yang lain tidak dapat menemui kesepakatan atau jalan keluar.
4. Perlu dirumuskan tindak pidana yang dapat memberikan kenyamanan dan kepastian hukum bagi kedua belah pihak dalam hal ini dokter dan pasien sehingga Dokter merasa nyaman di dalam menjalankan tugasnya sebagai dokter tanpa adanya rasa takut yang berlebihan dan di pihak pasien dapat memberikan perlindungan hukum apabila terjadi hal - hal yang menyimpang atau menimbulkan akibat tertentu yang merugikan pasien atau korban, Ini semua diperlukan demi terciptanya kepastian hukum bagi kedua belah pihak

\section{DAFTAR PUSTAKA}

Hukum. Malang: Bayumedia.

Ameln, Kapita Selekta Hukum Kedokteran. Jakarta :

Grafikatama Jaya, 1991.

Amri, Amir, Bunga Rampai Hukum Kesehatan. Jakarta : Widya Medika, 1997.

Achdiat, Crisdiono . Pernik - Pernik

Hukum Kedokteran Melindungi

Pasien dan Dokter. Jakarta :

Widya Medika,1996.

Chazawi, Adami, Kejahatan Terhadap

Tubuh dan Nyawa. Jakarta : PT

Raja Grafido Persada, 2000.

pemalsuan. Jakarta : PT Raja
Grafindo Persada .2001
, Malpraktik Kedokteran

Tinjauan Norma dan Doktrin
2007

Chairul, Huda. Dari Tiada Pidana Tanpa Kesalahan menuju Kepada Tiada Pertanggungjawaban Pidana Tanpa Kesalahan. Jakarta: Pranada Media. 2006

Dahlan, Sofwan . Hukum Kesehatan dan Rambu - Rambu Bagi Profesi Dokter Edisi 3. Semarang: Balai Penerbit UNDIP. 1999

Guwandi, Dokter Pasien dan Hukum. Jakarta : Fakultas Kedokteran UI, 1996.hal11. , Hukum Medik . Jakarta: Balai Penerbit FK UI 1996

$\begin{array}{lr}\text { Etika dan } & \text { Hukum } \\ \text { Kedokteran.Jakarta : } & \text { Balai } \\ \text { Penerbit FK UI, 1991. } & \end{array}$




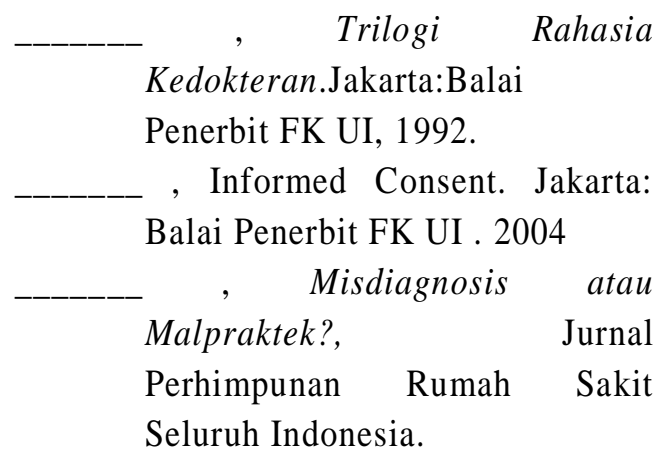

, Medical Error dan Hukum

Medis. Jakarta: Balai Penerbit

FK UI . 2005

Hermin, Hadiati . Beberapa

Permasalahan Hukum dan

Medik. Bandung: PT Citra Aditya

Bakti . 1992

Nawawi Barda Arief, Masalah Penegakan

Hukum Pidana dalam

Penanggulangan Kejahatan.

Jakarta, Kencana Prenada Media Group, 2008

Beberapa Masalah

Perbandingan Hukum Pidana.

Jakarta: PT Raja Grafindo

Persada. 2004

, Perbandingan Hukum Pidana.

Jakarta: PT Raja Grafindo

Persada. 2008

, Bunga Rampai Kebijakan

Hukum Pidana.Bandung: PT

Citra Aditya Bakti. 2002
, Masalah Penegakan Hukum dan Kebijakan Hukum Pidana dalam Penanggulangan Kejahatan . Jakarta: Prenada Media Group. 2007 , Kebijakan Legislatif Dalam Penanggulangan Kejahatan Dengan Pidana Penjara. Semarang: Badan Penerbit Undip 1996

Nyoman Serikat Putra Jaya, Kapita Selekta Hukum Pidana, Badan Penerbit Universitas Diponegoro, Semarang,2001.

Ngesti, Lestari , Masalah Malpraktik Etik dalam Praktik Dokter.Malang: Kumpulan Makalah Seminar Tentang Etika dan Hukum Kedokteran, 2001.

\section{Peraturan - Peraturan}

KUHP ( Kitab Undang - Undang Hukum Pidana )

Konsep KUHP 2008

UU No.23 Tahun 1992 tentang Kesehatan.

UU No. 36 Tahun 2009 tentang Kesehatan

UU No. 29 Tahun 2004 tentang Praktek Kedokteran. 